\title{
PENGARUH KECEPATAN TERHADAP PENINGKATAN KEMAMPUAN LOMPAT JAUH MAHASISWA UNIT KEGIATAN MAHASISWA OLAHRAGA
}

\author{
Alimuddin ${ }^{1}$, Nugroho Susanto ${ }^{2}$ \\ ${ }^{1}$ Universitas Negeri Padang, Ilmu Keolahragaan, Padang, Indonesia \\ ${ }^{2}$ Universitas Negeri Padang, IImu Keolahragaan, Padang, Indonesia \\ alimuddin@fik.unp.ac.id.nugrohosusanto@fik.unp.ac.id
}

\begin{abstract}
The long jump sport is not as easy as what we might see on its implementation. This sports branch also has special techniques to do so. Many people have done so, but the results of the expected jumps do not match in reality. The purpose of this research is to know the contributions that are given the physical ability of speed to the student jumping capability of SME sports. The type of research done is simple experimental research. The population of this research is a student of UKM sports. Sampling in this study, authors refer to sampling techniques that are nonprobability of saturated samples. The test is done with a 6second quick run test. Based on a summary of the results of the descriptive analysis in the table above about the speed data of the UKM sports, it can be described that speed data, of 15 samples were obtained the total value of 712.00 . The average value obtained $=47.4667$ with the standard deviation result $=$ 6.15127 . For the number range $=18.00$ is derived from the difference between the minimum value $=40.00$ and the maximum value $=58.00$ Evident from the results of the analysis $(\rho<0.05)$ or Ho rejected and $\mathrm{H} 1$ accepted, the results were obtained when associated with the skeletal thinking and the underlying theories and basically the results of this research supporting the theory.
\end{abstract}

Key words : Whey protein, eccentric exercise, muscle damaged

\begin{abstract}
Abstrak
Olahraga lompat jauh tidak semudah apa yang mungkin kita lihat pada pelaksanaanya. Cabang olahraga ini juga memiliki teknik-teknik khusus untuk melakukannya. Banyak orang yang telah melakukannya, namun hasil lompatan yang diharapkan tidak sesuai dengan kenyataannya. Tujuan dari penelitian ini adalah untuk mengetahui kontribusi yang diberikan kemampuan fisik kecepatan terhadap kemampuan lompatan mahasiswa UKM Olahraga. Jenis penelitian yang dilakukan adalah penelitian eksperimen sederhana. Adapun yang dijadikanpopulasipenelitianiniadalahmahasiswaUKM Olahraga. Pengambilan sampel pada penelitian ini, penulis mengacu pada teknik pengambilan sampel yang sifatnya nonprobabilitas yaitu sampeljenuh. Tes yang dilakukan yaitu dengan tes Lari cepat 6 detik. Berdasarkan rangkuman hasil analisis deskriptif pada tabel di atas tentang data kecepatan UKM Olahraga maka dapat diuraikan bahwa data
\end{abstract}


kecepatan, dari 15 jumlah sampel diperoleh total nilai sebanyak 712.00 . Nilai ratarata yang diperoleh $=47.4667$ dengan hasil standar deviasi $=6.15127$. Untuk angka range $=18.00$ diperoleh dari selisih antara nilai minimal $=40.00$ dan nilai maksimal $=58.00$

Terbukti dari hasil analisis $(\rho<0.05)$ atau $\mathrm{H}_{\circ}$ ditolak dan $\mathrm{H}_{1}$ diterima, maka hasil yang diperoleh tersebut apabila dikaitkan dengan kerangka berfikir dan teori-teori yang mendasarinya dan pada dasarnya hasil penelitian ini mendukung teori yang ada.

Kata kunci : Jump away, speed, contribute

\section{PENDAHULUAN}

Unit Kegiatan Mahasiswa (UKM) Olahraga terdiri dari berbagai jurusan yang berada dalam lingkup kegiatan mahasiswa yang melakukan pendampingan terhadap olahraga. Pembinaan yang mereka lakukan hanya pada cabang olahraga yang beregu sehingga melupakan olahraga-olahraga individu. Padahal kita bisa melihat dan mencari bibit-bibit atlet lompat jauh di unit-unit kegiatan mahasiswa seperti ini.

Olahraga lompat jauh bukan hal yang mudah untuk dilakukan. Olahraga ini juga membutuhkan latihan-latihan khusus serta pembinaan-pembinaan yang ekstra maksimal utamanya dari usia dini karena untuk menghasilkan atlet yang maksimal ada beberapa komponen-komponen tubuh yang akan dituntun pada kondisi yang seharusnya. Olahraga lompat jauh merupakan olahraga yang mengharuskan semua orang atau atlet yang melakukannya memiliki suatu kemampuan khusus. Olahraga lompat jauh tidak semudah apa yang mungkin kita lihat pada pelaksanaanya. Cabang olahraga ini juga memiliki teknik-teknik khusus untuk melakukannya. Dikdik Zafar Sidik (2010:65) juga berpendapat mengengenai teknik lompat jauh bahwa rangkaian lompat jauh terbagi dalam beberapa fase yaitu awalan, tolakan, melayang dan mendarat.Banyak orang yang telah melakukannya, namun hasil lompatan yang diharapkan tidak sesuai dengan kenyataannya.

Pada hakekatnya lompatan seseorang juga berkaitan dengan beberapa komponen tubuh lainnya. Salah satunya yaitu komponen kecepatan seseorang. Untuk memperoleh lompatan yang jauh otomatis kita tetap berkiblat pada teknikteknik cabang olahraga ini, salah satunya yaitu awalan. Dimana pada prosesnya awalan juga mengacu pada cabang atletik nomor lari dimana yang berpengaruh besar untuk melakukan lari vaitu kemampuan seseorang untuk menempuh jarak 
tertentu secepat mungkin. Namun pada olahraga lompat jauh seseorang tidak dituntun lari begitu saja, tetapi harus mengontrolnya dengan baik karena masih ada tahap-tahap selanjutnya seperti tolakan pada papan tumpuan. Pada saat tolakan, yang berpengaruh besar adalah daya ledak tungkai yang dihasilkan sehingga mampu mempengaruhi jarak lompatan.

\section{METODELOGI PENELITIAN}

Jenis penelitian yang dilakukan adalah penelitian eksperimen sederhana. Adapun yang akandijadikansampelpenelitianiniadalahmahasiswaUKM Olahraga. Pengambilan sampel pada penelitian ini, penulis mengacu pada teknik pengambilan sampel yang sifatnya nonprobabilitas yaitu sampeljenuh yang merupakan teknik penentuan sampel bila semua anggota populasi digunakan sebagai sampel. Pada penelitian ini, metode yang digunakan dalam pengumpulan data adalah mencatat semua hasil tes yang diberikan kepada sampel dalam hal ini mahasiswa UKM Olahraga. Tes yang dilakukan yaitu dengan tes Lari cepat 6 detik (Nur Ichsan Halim, 2011). Analisis yang digunakan adalah analisis statistik deskriptif yang meliputi rata-rata hitung atau mean, median, modus dan standar deviasi. selanjutnya yang akan ditempuh dalam analisis data penelitian ini setelah uji deskritif yaitu uji regresi data untuk membuktikan adanya kontribusi kecepatan yang diberikan terhadap kemampuan lompat jauh.

\section{HASIL PENELITIAN}

Data hasilteskecepatan, terhadapkemampuan lompat jauh mahasiswa UKM Olahraga yang diperolehdalampenelitianakandianalisisdenganteknikstatistikdeskriptifmaupunstati stikkorelasi. Bedasarkan rangkuman hasil analisis deskriptif pada tabel di atas tentang data kecepatan UKM Olahraga maka dapat diuraikan bahwa Untuk data kecepatan, dari 15 jumlah sampel diperoleh total nilai sebanyak 712.00. Nilai ratarata yang diperoleh $=47.4667$ dengan hasil standar deviasi $=6.15127$. Untuk angka range $=18.00$ diperoleh dari selisih antara nilai minimal $=40.00$ dan nilai maksimal $=58.00$.

Data kecepatan diperoleh melalui tes lari 6 detik. Untuk mengetahui keeratan kontribusi kecepatan terhadap kemampuan lompat jauh dilakukan analisis regresi tunggal dengan rangkuman hasil analisis sebagai berikut: 
Tabel 1. Rangkuman hasil analisis regresi kecepatan terhadap kemampuan lompat jauh

\begin{tabular}{|c|c|c|c|c|}
\hline Variabel & $\boldsymbol{\beta}$ & $\mathbf{t}_{\mathbf{0}}$ & $\boldsymbol{\rho}$ & Ket. \\
\hline $\begin{array}{c}\text { KCPT (X1) } \\
\text { KLJH (Y) }\end{array}$ & 0.899 & 7.416 & 0.000 & Signifikan \\
\hline
\end{tabular}

Berdasarkan tabel di atas terlihat bahwa hasil perhitungan regresi tunggal, diperoleh $\beta=0.899$, dengan nilai t hitung $\left(t_{0}\right)=7.416(\rho<0.05)$, berarti ada kontribusi yang signifikan kecepatan terhadap kemampuan lompat jauh pada mahasiswa UKM Olahraga. Dengan demikian jika mahasiswa memiliki kecepatan yang baik akan diikuti dengan kemampuan lompat yang jauh.

\section{PEMBAHASAN}

Terbukti dari hasil analisis $(\rho<0.05)$ atau $\mathrm{H}_{0}$ ditolak dan $\mathrm{H}_{1}$ diterima, maka hasil yang diperoleh tersebut apabila dikaitkan dengan kerangka berfikir dan teori-teori yang mendasarinya dan pada dasarnya hasil penelitian ini mendukung teori yang ada.Hasilanalisisinidapatdijelaskanbahwakecepatanmemberikankontribusiterhada pkemampuanlompatjauhsebesar $\quad 80.90 \%$ sedangkan sisanya $\quad 19.10 \%$ dijelaskanolehvariabel lain yang tidakdiamatidalampenelitianini.

Hal ini dapat dijelaskan bahwa apabila mahasiswa UKM Olahraga memiliki kecepatan yang cepat, akan memberikan daya dorong yang kuat pada saat menumpu. Dimana kecepatan merupakan proses gerakan berlari dengan kecepatan penuh yang dilanjutkan dengan tumpuan yang kuat. Sehingga unsur fisik kecepatan tidak boleh diabaikan dikarenakan sangat berpengaruh bagi kemampuan lompat jauh. Hal tersebut mendukung teori yang ada seperti yang dijelaskan Jess Jarver (2012:25) menyatakan bahwa tahap lari merupakan tahap pertama dari serangkaian gerakan dalam cabang lompat jauh. Jadi pelompat yang ingin mencapai hasil lompatan yang maksimal, baik dari segi ketepatan tumpuan maupun dari segi jaraknya dituntut suatu kecepatan pada saat awalan dengan langkah kaki yang tepat, agar dapat bertumpu pada balok tumpuan dengan tepat. Selain itu kecepatan juga merupakan faktor pendukung yang sangat penting untuk melahirkan gerak lompatan yang lebih baik dan efisien. 
Darihasil

analisis

data

yang

diolahdenganperhitunganstatistikmelaluiprogramStatistical Product and Service Sistem (SPSS)

dan

hasilpengujianhipotesissertadaripembahasan,makahasilpenelitianinidisimpulkan

bahwa Ada kontribusi yang signifikanantara kecepatan terhadap kemampuan lompat jauh mahasiswa UKM Olahraga

\section{SARAN}

Berdasarkanhasilpenelitian yang disimpulkantersebut di atas, makapenelitimemberikansaran-saran agar dapat meningkatkan kemampuan lompat jauh maka yang utama perlu diperhatikan yaitu kecepatan

\section{DAFTAR PUSTAKA}

Nur IchsanHalim. 2011. Tes dan Pengukuran Kesegaran Jasmani. Badan Penerbit UNM. Makassar.

Jarver Jess. 2012. Belajar dan berlatih atletik. Pionir Jaya: Bandung.

Sidik Zafar Dikdik. 2010. Mengajar dan melatih atletik. Remaja Rosdakarya: Bandung. 